\title{
Has the OECD Guidance Helped Reduce Mal-Corporate Behavior?
}

\section{Abbott Haron*}

MBA, Higher Colleges of Technology, Sharjah, Sharjah, UAE

*Corresponding author: Dr. Abbott Haron, MBA, Higher Colleges of Technology, Sharjah, Sharjah, UAE, Tel: +374 10 23-72-61; E-mail: abbottjharon@hotmail.com Received date: December 05, 2014, Accepted date: January 19, 2015, Published date: January 27, 2015

Copyright: (C) 2015 Haron A. This is an open-access article distributed under the terms of the Creative Commons Attribution License, which permits unrestricted use, distribution, and reproduction in any medium, provided the original author and source are credited.

\section{Introduction}

A Winning Governance Structure should to follow the guidelines or principals set by the OECD; The OECD Principles of Corporate Governance have become an international standard for policy makers, investors, corporations and other stakeholders globally [1]. They have advanced the corporate governance agenda and delivered specific direction for legislative and regulatory initiatives in both OECD and non-OECD countries. According to Anca [1], the Financial Stability Forum has designated the Principles as one of the 12 key standards for complete financial systems. The Principles similarly aid cooperation between OECD and non-OECD countries and reinforce the corporate governance element of World Bank and IMF Reports on the Observance of Standards and Codes [2].

Policy makers in OECD and non-OECD countries are now more aware of the influence good corporate governance makes to financial market stability, investment, and economic development. Companies can better understand how sound corporate governance contributes to their competitiveness. Investors realize they have a part to play in ensuring good corporate governance practices [2]. In the new world economy, interest in corporate governance goes past that of stockholders in the performance of particular companies. As corporations play an essential role in our economies and we rely increasingly on private sector organizations to secure retirement incomes and manage personal savings, sound corporate governance is important to extensive and growing segments of the world's population [3].

\section{The Components}

The components we picked as the foundation of our winning governance structure are going to follow the structure set by Monks and Minow [4] in their book on corporate governnance. Our components fit into the following framework:

- Shareholders Ownership and Equal Rights.

- Following Institutional and Government Regulations

- Managing Performance through Shareholders.

- The Board, Transparency, and Disclosure.

\section{Shareholders ownership and equal rights}

Shareholders rights and, ownership tasks must protect and facilitate the implementation of shareholders' rights [5]. Shareholder rights ought to include the right to; secure ownership registration; take or transfer shares; acquire pertinent information on the corporation on a timely and regular basis; join and vote in general stockholder meetings; elect and eliminate members of the board; and share in the profits of the firm [6].
According to Monks and Minow [4], shareholders need to have the right to take part in, and to be informed on, decisions concerning essential corporate changes such as: changes to the statutes; the sanction of additional shares; and extraordinary transactions, including the transfer of all or significantly all their assets. Shareholders need to have the opportunity to take part in voting in general shareholder meetings and be up-to-date on the rules, including voting procedures, which administer general stockholder meetings. The capital structures and provisions, which enable certain shareholders to attain a degree of control inconsistent to their equity ownership, should be revealed [7]. The acquisition of corporate control should be allowed to operate in a well-organized and transparent method. The rules and procedures governing the acquisition of corporate control should be clearly expressed and revealed so that investors understand their rights and options. Trades should occur at transparent prices and under fair conditions that protect the rights of all stockholders, and anti-take-over strategies should not be used to safeguard management and the board from responsibility [6].

In addition, the corporate governance structure must ensure the fair treatment of all shareholders, including minority and foreign shareholders [7]. All shareholders should have the opportunity to gain effective compensation for violation of their rights. Investors' assurance that the capital they provide will be protected from misuse or misappropriation by corporate managers or board members, is an vital factor in the capital markets [8]. Company managers may have the opportunity to engage in activities that may advance their own interests at the expense of non-controlling stockholders, by providing protection to shareholders [9]. In areas where the enforcement of the legal and regulatory structure is weak, some countries have found it desirable to reinforce the rights of shareholders such as by low share ownership thresholds for placing items on the agenda of the stockholders meeting or by requiring a supermajority of shareholders for certain significant decisions [4]. The Philosophies support equal handling of foreign and domestic shareholders in corporate governance. They do not address government policies to police foreign direct investment [4].

According to Monks and Minow [4], all shareholders must be treated equally, within any series of a class; all shares must have the same rights, all investors must be able to obtain information about their rights before they purchase. Any alterations to voting rights must be subject for approval by those classes of shares, which are negatively affected. In addition, minority shareholders must be protected from abusive actions by, or in the interest of, controlling shareholders acting either directly or indirectly, and should have effective means of compensation. 


\section{Following institutional and government regulations}

To ensure the basis for an effective corporate governance framework, the corporate governance framework should encourage transparent and efficient markets, be consistent with the law of the land and clearly define the division of responsibilities among different managerial, regulatory and enforcement authorities [2].

According to Pande and Ahmad [10], the corporate governance framework must be established with a view on its impact on economic performance of the corporation, market reliability and the encouragement it creates for market members and the advancement of transparent and efficient markets. Furthermore, to guarantee an effective corporate governance framework; it is essential that a suitable and effective legal, regulatory and institutional foundation is created, on which all market members can rely in establishing their private contractual dealings [10]. The fore mentioned corporate governance framework usually includes elements of legislation, regulation, selfregulatory measures, voluntary obligations and business practices that are the result of a country's specific situations, history and tradition [6] Nevertheless, this mix will vary from country to country because of the dynamism of its components. When business gains more experience and conditions change, the content and structure of this framework might need to be adjusted to account for the changes in the micro and macro environments [8]. Therefore, the legal and regulatory requirements that influence corporate governance practices in any location should be consistent with the rule of law, transparent and enforceable. In addition any separation of responsibilities among different authorities in a country should be clearly expressed and in the public's best interest. The mentioned authorities must have the power, integrity, and resources to achieve their duties in a professional and impartial manner [4].

\section{Managing performance through shareholders}

The role of Investors in Corporate Governance should recognize the rights of stakeholders established by law or through joint agreements and inspire active co-operation between businesses and stakeholders in creating wealth [9]. One crucial aspect of corporate governance is concerned with safeguarding the flow of capital to corporations. Corporate governance is also concerned with sourcing ways to encourage the numerous stakeholders in the firm to undertake economic investments in the firm's human and physical capital [4]. Additionally, the governance framework must recognize that the interests of the company are served by recognizing the interests of stakeholders and their contribution to the long-term success of the firm. Furthermore, the subsequent are specific points aimed at enforcing the commitments to the fact that the rights of stakeholders must be respected, they must have the opportunity to obtain effective compensation for violation of their rights, they must have access to relevant, adequate, and dependable information in a timely and regular manner, they should be able to freely communicate their anxieties about illegal or unethical practices to the board and their rights should not be compromised for doing that [11]. Finally, the framework should be complemented with an effective, efficient insolvency framework and by effective execution of creditor rights [4].

\section{The board, transparency and disclosure}

The duties of the board should ensure the strategic leadership of the company, the effective monitoring of the executives, and full accountability to the corporation and the shareholders [4]. Board structures and procedures vary both within and among OECD nations. Some nations have split-level boards that separate the supervisory function and the management functions into different bodies [1]. Such systems typically have a "supervisory board" made-up of non-executive board members and a "management board" made-up entirely of executives. Other nations have "unitary" boards, which combines executive and non-executive board members [1]. In some countries, there is also an additional legal body for audit purposes. The Principles are intended to be adequately general to apply to whatever board structure is charged with the roles of governing the enterprise and observing management [1]. Furthermore, board members must act on fully well informed basis, in good faith, with due diligence and caution, and in the best interest of the business and the stockholders, where board decisions may affect different stockholder groups differently. They must treat all stockholders justly; they must apply high ethical standards and take into account the interests of investors by fulfilling certain important functions. Including: Reviewing and guiding corporate strategy, monitoring the effectiveness of the company's governance practices, choosing, rewarding, monitoring, and, if necessary, replacing key executives, bring into line key executive and board compensation with the longer-term interests of the company and its investors, safeguarding a formal and transparent board nomination and selection process, monitoring and managing possible conflicts of interest, ensuring the honesty of the organization's accounting and financial reporting systems, managing the process of disclosure and communications [4].

The board must be able to exercise impartial independent decision on corporate affairs. For example: boards must consider assigning a sufficient number of non-executive board members capable of exercising independent judgment to tasks where there is a potential for conflict of interest [12]. Examples of such key responsibilities are ensuring the honesty of financial and non-financial reporting, the evaluation of related party transactions, selection of board members and key executives, and board compensation. When a committee of the board is created, their directive, configuration, and working methods must be well defined and revealed by the board. The board members must be able to bind themselves effectively to their duties. To be able to fulfill their duties; board members must have access to precise, appropriate data in a timely manner [4].

The corporate governance structure must ensure the well-timed and precise disclosure on matters regarding the company, including the monetary situation, performance, ownership, and governance of the company [13-19]. Public disclosure is usually required at a minimum, on a yearly basis; however, some countries require periodic disclosure on a semi-annual or quarterly basis, or even more regularly in the case of material developments affecting the corporation [2]. Companies should make voluntary disclosure beyond the slightest disclosure requirements in response to market demand. The disclosure should include, but not be limited to, information on: The financial and operating results of the corporation, company objectives, key share ownership, and voting rights, compensation policy for members of the board and key executives. In addition to information about board members, including their credentials, the selection process, related party transactions, predictable risk factors, matters concerning employees and other stakeholders, governance procedures and policies, and the process by which they are applied, financial information must be organized and disclosed in accordance with high quality principles of accounting disclosure, an annual audit must be conducted by an independent, capable and qualified auditor. This must be done to provide an external and impartial assurance to the board and 
stockholders that the financial declarations honestly represent the financial position and performance of the corporation, the external auditors must be accountable to the investors and owe a duty of care to the company to exercise due professional care and diligence in the conduct of the audit, the channels for distributing information must provide for timely, cost-efficient and equal access to all relevant information to stakeholders, the corporate governance structure must be accompanied by an effective approach that addresses and endorses the delivery of analysis, advice by analysts and rating agencies, free from conflicts of interest which might compromise the integrity of the advice [4].

\section{References}

1. Anca P (2012) Corporate Governance: Principles and Regulations. J of Electrical and Electronics Engineering 5: 155-160.

2. Cosneanu S, Russu C, Chiriţescu V, Badea L (2013) Foundations and Principles of Corporate Governance. Valahian J of Econ Stud 4: 31-38.

3. Hilb M (2005) New Corporate Governance: from good guidelines to great practice. New Corporate Governance 13: 269-581.

4. Monks RA, Minow N (2011) Corporate Governance. John Wiley and Sons.

5. Irvine W (1988) Corporate Democracy and the Rights of Shareholders. J of Bus Ethics 7: 99.

6. Mallin C, Melis A (2012) Shareholder rights, shareholder voting, and corporate performance. J Manage Gov16: 171-176.

7. Beck A (1989) Company Law: Minority Shareholders And Allotments For An I. Aus Bus Law Rev 17: 321.
8. Wanyama S, Burton B, Helli C (2009) Frameworks Underpinning Corporate Governance: Evidence on Ugandan Perceptions. Corporate Governance: An Int Rev 17: 159-175.

9. Wright M, Filatotchev I, Buck T, Bishop K (2003) Is Stakeholder Corporate Governance Appropriate in Russia? J of Manage and Gov 7: 263-290.

10. Pande S, Ahmad VA (2014) A Theoretical Framework for Corporate Governance. Ind J of Corporate Gov 7: 56-72.

11. Tuan LT (2012) Corporate social responsibility, ethics, and corporate governance. Social Responsibility J 8: 547-560.

12. Jesover F (2001) Corporate Governance in the Russian Federation: the relevance of the OECD Principles on shareholder rights and equitable treatment. Practice-based Papers 9: 79-84.

13. Ananymous (2014) NCC Moves to Enhance Stakeholders' Role With Corporate Governance Code.

14. Demidenko E, McNutt P (2010) The ethics of enterprise risk management as a key component of corporate governance. Int J of Social Econ 37: 802-815.

15. Döscher T, Friedl G (2011) Corporate governance, stakeholder power, and executive compensation. OR Spectrum 33: 309-331.

16. Jo H, Harjoto MA (2011) Corporate Governance and Firm Value: The Impact of Corporate Social Responsibility. J of Bus Ethics 103: 351-383.

17. Kulkani R, Maniam B (2014) Corporate Governance-Indian Perspective. Int J of Trade, Econ and Financ 5: 364-368.

18. Windsor D (2009) Tightening corporate governance. J of Int Manage 15: 306-316.

19. Carney M, Gedajlovic E, Sur S (2010) Corporate governance and stakeholder conflict. J Manage Gov 15: 483-507. 